\title{
EMMA BY JANE AUSTEN
}


General Editor: James Gibson

Published:

JANE AUSTEN: EMMA Norman Page

ROBERT BOLT: A MAN FOR ALL SEASONS Leonard Smith

EMILY BRONTË: WUTHERING HEIGHTS Hilda D. Spear

GEOFFREY CHAUCER: THE PROLOGUE TO THE CANTERBURY

TALES Nigel Thomas and Richard Swan

CHARLES DICKENS: GREAT EXPECTATIONS Dennis Butts

GEORGE ELIOT: SILAS MARNER Graham Handley

GEORGE ORWELL: ANIMAL FARM Jean Armstrong

WILLIAM SHAKESPEARE: MACBETH David Elloway

A MIDSUMMER NIGHT'S DREAM

Kenneth Pickering

ROMEO AND JULIET Helen Morris

Forthcoming:

JANE AUSTEN: MANSFIELD PARK Richard Wirdnam

PRIDE AND PREJUDICE Raymond Wilson

CHARLES DICKENS: HARD TIMES Norman Page

GEORGE ELIOT: MIDDLEMARCH Graham Handley

T. S. ELIOT: MURDER IN THE CATHEDRAL Paul Lapworth OLIVER GOLDSMITH: SHE STOOPS TO CONQUER Paul Ranger THOMAS HARDY: FAR FROM THE MADDING CROWD

Colin Temblett-Wood

TESS OF THE D'URBERVILLES James Gibson

CHRISTOPHER MARLOWE: DR FAUSTUS David Male

THE METAPHYSICAL POETS Joan van Emden

WILLIAM SHAKESPEARE: HAMLET Jean Brooks

TWELFTH NIGHT Edward Leeson

THE WINTER'S TALE Diana Devlin

GEORGE BERNARD SHAW: ST JOAN Leonee Ormond

R. B. SHERIDAN: THE RIVALS Jeremy Rowe

Also published by Macmillan

MACMILLAN MASTER SERIES

Mastering English Literature R. Gill

Mastering English Language S. H. Burton

Mastering English Grammar S. H. Burton 


\section{MACWILLAN MASTER GUIDES}

\section{EMMA}

\section{BY JANE AUSTEN}

NORMAN PAGE

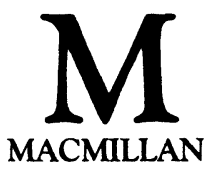




\section{(C) Norman Page 1985}

All rights reserved. No reproduction, copy or transmission of this pablication may be made without written permission.

No paragraph of this publication may be reproduced, copied or transmitted save with written permission or in accordance with the provisions of the Copyright Act 1956 (as amended).

Any person who does any unauthorised act in relation to this publication may be liable to criminal prosecution and civil claims for damages.

First edition 1985

Published by

\section{MACMILLAN EDUCATION LTD}

Houndmills, Basingstoke, Hampshire RG21 2XS

and London

Companies and representatives

throughout the world

Typeset by

TECSET, Sutton, Surrey

British Library Cataloguing in Publication Data

Page, Norman

A Macmillan master guide to Emma.-

(Macmillan master guides)

1. Austen, Jane. Emma

I. Title

823'.7 PR4034.E53

ISBN 978-0-333-38005-5

ISBN 978-1-349-07623-9 (eBook)

DOI 10.1007/978-1-349-07623-9 


\section{CONTENTS}

General editor's preface

vii

Acknowledgement

ix

1 Jane Austen: life and background

2 Summaries and critical

2.1 Introduction commentary

2.2 Chapter summaries and commentaries

3 Themes and issues

3.1 Growing up towards marriage

3.2 The social world of Highbury

4 Techniques

4.1 Plot and structure

4.2 Narrative point of view

4.3 Methods of characterisation

4.4 Language and style

5 Specimen passage and

5.1 Specimen passage commentary

5.2 Commentary

6 Critical appraisals

Revision questions

Further reading 


\section{GENERAL EDITOR'S PREFACE}

The aim of the Macmillan Master Guides is to help you to appreciate the book you are studying by providing information about it and by suggesting ways of reading and thinking about it which will lead to a fuller understanding. The section on the writer's life and background has been designed to illustrate those aspects of the writer's life which have influenced the work, and to place it in its personal and literary context. The summaries and critical commentary are of special importance in that each brief summary of the action is followed by an examination of the significant critical points. The space which might have been given to repetitive explanatory notes has been devoted to a detailed analysis of the kind of passage which might confront you in an examination. Literary criticism is concerned with both the broader aspects of the work being studied and with its detail. The ideas which meet us in reading a great work of literature, and their relevance to us today, are an essential part of our study, and our Guides look at the thought of their subject in some detail. But just as essential is the craft with which the writer has constructed his work of art, and this is considered under several technical headings - characterisation, language, style and stagecraft.

The authors of these Guides are all teachers and writers of wide experience, and they have chosen to write about books they admire and know well in the belief that they can communicate their admiration to you. But you yourself must read and know intimately the book you are studying. No one can do that for you. You should see this look as a lamppost. Use it to shed light, not to lean against. If you know your text and know what it is saying about life, and how it says it, then you will enjoy it, and there is no better way of passing an examination in literature.

JAMES GiBSON 


\section{ACKNOWLEDGEMENTS}

Cover illustration: $A$ View of the Avon Gorge by Francis Danby, courtesy of the City of Bristol Museum and Art Gallery and the Bridgeman Art Library. 